\title{
TINGKAT KECEMASAN SEBELUM BERTANDING DAN PERCAYA DIRI PADA SAAT BERTANDING ATLET PELATDA PENGPROV FPTI SUMATERA SELATAN
}

\author{
Bayu Hardiyono
}

Bina Darma University, email : bayu.hardiyono@binadarma.ac.id

\begin{abstract}
Abstrak
Penelitian ini adalah penelitian deskriptif yang bertujuan untuk mengetahui Tingkat Kecemasan dan Percaya Diri Atlet Panjat Tebing Sumatera Selatan sebelum pertandingan . Sampel pada penelitian ini berjumlah 30 atlet daerah. Metode yang digunakan adalah survei dengan angket sebagai intrumen pengambilan data. Analisis data menggunakan teknik analisis deskriptif dengan persentase. Hasil penelitian tingkat kecemasan dan percaya diri atlet pelatda cabang olahraga Panjat tebing sebelum menghadapi pertandingan dan pada saat bertanding, pada faktor intrinsik dan ekstrinsik, Untuk hasil analisis kecemasan faktor intrinsik dalam kategori rendah $14.78 \%$, hal ini berarti kecemasan atlet panjat tebing sebelum menghadapi pertandingan dipengaruhi oleh faktor intrinsik. sedangkan untuk hasil analisis kecemasan faktor ekstrinsik dalam kategori tinggi $85.22 \%$, hal ini berarti kecemasan atlet panjat tebing sebelum menghadapi pertandingan sangat dipengaruhi oleh faktor ekstrinsik. Sedangkan hasil Untuk hasil analisis percaya diri faktor intrinsik dalam kategori tinggi $80.245 \%$ hal ini berarti percaya diri atlet panjat tebing pada saat pertandingan dipengaruhi oleh faktor intrinsik. Untuk Hasil analisis faktor ekstrinsik dalam kategori tinggi $19.755 \%$. hal ini berarti percaya diri atlet panjat tebing pada saat pertandingan sangat dipengaruhi oleh faktor ekstrinsik.
\end{abstract}

Kata Kunci : Kecemasan, Percaya Diri.

\begin{abstract}
Abstrack
This research is a descriptive study that aims to determine the Level of Anxiety and Confidence in the South Sumatra Rock Climbing Athletes before the match. The sample in this study amounted to 30 regional athletes. The method used is a survey with a questionnaire as a data collection instrument. Data analysis using descriptive analysis techniques with percentages. The results of the anxiety and confidence level of athletes in the local sport branch of rock climbing before facing the match and when competing, on intrinsic and extrinsic factors, for the results of anxiety analysis intrinsic factor in the low category of $14.78 \%$, this means the anxiety of rock climbing athletes before facing the match is influenced by intrinsic factors. while for the results of the analysis of anxiety the extrinsic factor is in the high category $85.22 \%$, this means that the anxiety of a rock climbing athlete before facing a match is strongly influenced by the extrinsic factor. While the results for the analysis of self-confidence intrinsic factor in the high category $80.245 \%$ this means that the confidence of rock climbing athletes during the game is influenced by intrinsic factors. For the analysis of extrinsic factors in the high category $19.755 \%$. this means that the confidence of a rock climbing athlete during a match is greatly influenced by extrinsic factors.
\end{abstract}

Keywords: Anxiety, Confidence. 


\section{PENDAHULUAN}

Olahraga merupakan hal yang kompleks, Olahraga dapat dilihat dari berbagai macam sudut pandang. Terkait dengan pencapaian prestasi sebagai salah satu tujuan dari olahraga, banyak faktor yang mempengaruhi dalam pencapaian prestasi tersebut. Menurut Hardiyono, B. (2019), Olahraga adalah upaya dalam meningkatkan kualitas hidup manusia, Selain tujuan utamanya untuk membentuk pola hidup yang sehat, melalui kegiatan berolahraga seseorang akan memperoleh manfaat, salah satunya adalah sistem metabolism tubuhakan menjadi lancar.

Faktor fisik, psikis, lingkungan, dan faktor lainya dapat mempengaruhi seseorang dalam proses pencapaian prestasi. Salah satu faktor yang memberikan kontribusi dalam pencapaian prestasi adalah faktor psikis. Faktor psikis adalah faktor yang muncul dari psikis seseorang seperti ketegangan, kegairahan, percaya diri dan kecemasan. Setiap atlet atau pemain pasti pernah merasakan ketegangan, kegairahan, kecemasan dan percaya diri. Faktor-faktor tersebut merupakan gejolak psikis yang terjadi akibat adanya stimulus yang datang. Kecemasan dan percaya diri sebagai faktor psikis dapat mempengaruhi penampilan pemain dalam pertandingan. Tingkat kecemasan dan Percaya diri yang sangat tinggi dapat berakibat buruk pada penampilan seseorang. Kurang siapnya mental serta kurangnya keterampilan mengontrol dan keterampilan persepsi terhadap stimulus yang datang akan mengakibatkan terganggunya kemampuan pemain dalam mengeluarkan kemampuan fisik yang dimilikinya sehingga pemain tersebut tidak akan bisa all out. Apabila hal ini terjadi maka akan terjadi penurunan penampilan yang dapat membuat pemain tersebut mengalami kekalahan. Monty P. Setiadarma (2000:10-
11) menjelaskan bahwa psikologi Olahraga lebih diarahkan kepada kemampuan prestatif pelakunya yang bersifat kompetitif.

Selanjutnya menurut James Tangkudung dan Apta Mylsidayu (2017:10) psikologi olahraga adalah suatu ilmu yang mempelajari gejalagejala kejiwaan/tingkah laku yang terjadi pada olahragawan ketika mereka berolahraga. Tujuan diadakannya pertandingan panjat tebing baik resmi maupun tidak resmi selain meningkatkan motivasi untuk berprestasi, dapat memperkenalkan cabang olahraga panjat tebing pada khalayak umum agar dapat lebih dikenal dan di nikmati masyarakat umum. Walau demikian, cabang olahraga panjat tebing yang sudah banyak peminatnya dan pesaing-pesaing untuk menuju menjadi atlet yang berprestasi, sehingga atlet harus melatih mental sejak dini agar kelak menjadi atlet yang dapat mengendalikan kecemasan dan percaya diri pada saat menghadapi dan pada saat pertandingan. Penelitian ini lebih mengarah pada aspek mental menjelang pertandingan dan pada saat bertanding. karena pengaruh aspek mental tersebut secara khusus terlihat saat menjelang pertandingan dan pada saat pertandingan. Demikian besar pengaruh aspek mental sehingga seorang atlet yang telah mempersiapkan fisik sebaik-baiknya, mempersiapkan latihan teknik, taktik dengan baik dan telah di perdiksi untuk mendapat kemenangan.

Atlet pada kenyataannya terlalu cemas saat menghadapi suatu pertandingan sehingga harapan yang seharusnya dapat dicapai dengan mudah menjadi sulit, contoh lainnya yang mempertegas bahwa peranan aspek mental merupakan salah satu diantara aspek-aspek lainnya seperti fisik, teknik, strategi dan taktik yang menentukan penampilan atlet dalam pertandingan. 
Misalnya jadwal pertandingan yang mundur atau tidak sesuai dengan jadwal yang telah ditentukan, maka akan cenderung terjadi rasa cemas pada diri atlet yang selanjutnya dapat berpengaruh negatif terhadap prestasinya jika atlet harus mampu mengendalikan kecemasan dan stress dalam menghadapi suatu pertandingan agar dapat menampilkan prestasi yang optimalnya sesuai dengan tujuan yang diharapkan.

Berdasarkan uraian di atas bahwa aspek mental akan mempengaruhi prestasi atlet, sehingga tekanan mental yang terjadi pada seorang atlet dalam suatu pertandingan perlu ditangani oleh atlet bersangkutan maupun pihak-pihak terkait. Dalam melaksanakan progam latihan atlet dirasa telah memenuhi keseluruhan aspek dalam pencapaian prestasinya, kenyataan bahwa prestasi olahraga bulutangkis masih belum dapat ditampilkan secara optimal. Salah satunya dikarenakan aspek mental yang kurang dikuasai oleh atlet. Sehingga dalam pertandingan atlet belum bisa mengatasi kendala-kendala untuk mengurangi tingkat kecemasan dan stress pada diriya $\mathrm{Di}$ dalam penelitian ini diharapkan para atlet mampu dalam mengatasi gejala yang ada. Gejala tersebut meliputi gejala pada kecemasan dan rasa percaya diri yang atlet alami. Selain itu para pelatih juga harus mampu dan memberikan berbagai informasi tentang bagaimana cara atlet dalam mengatasi atau mengurangi rasa kecemasan dan rasa stress tersebut. Menurut Fauzul Iman (2012: 17) kecemasan merupakan masalah gejolak emosi yang sering menghadapi atlet, terutama pada cabang olahraga individu dengan kesulitan yang cukup tinggi. Sebagaimana diketahui perasaan manusia ada yang positif dan ada perasaan yang negatif. Perasaan positif seperti bahagia, senang, gembira. Perasaan negatif seperti kecewa, binggung, khawatir dan sebagainya. Tidak ada satu pun untuk mengembangkan perasaan negatif, tetapi seringkali tidak mempunyai pilihan lain, selain menghadapi keadaan yang tidak menyenangkan dan harus masuk dalam keadaan perasaan yang negatif. Sedangkan Menurut Levitt (Singgih D. Gunarsa, 2008:74) kecemasan dirumuskan sebagai "subjective feeling of apprehension and heightens physiological arousal". Kecemasan berbeda dari rasa takut biasa. Rasa takut dirasakan jika ancaman berupa sesuatuyang sifatnya objektif, spesifik, dan terpusat. Sementara itu, kecemasan disebabkan oleh suatu ancaman yang sifatnya lebih umum dan subjektif.

Kecemasan merupakan reaksi biasa atau sesuatu yang normal terjadi, misalnya dalam menghadapi suatu pertandingan. Menurut Husdarta (2010: 80) kecemasan dapat dibedakan menjadi dua yaitu kecemasan yang dirasakan oleh atlet dalam waktu tertetu, misalnya menjelang pertandingan (state anxiety) dan kecemasan yang dirasakan karena atlet tergolong pencemas (trait anxiety). Kecemasan adalah perasaan subjektif yang sulit dipahami penyebabnya oleh penderita. Ibrahim dan Komarudin (Fauzul Iman,2012: 22) menjelaskan bahwa: "Istilah Anxiety (kecemasan) merupakan suatu perasaaan subjektif berupa kekhawatiran dan meningkatkan ketegangan secara psikologis. Konsep ini hampir sama dengan rasa takut yang memiliki objek yang jelas, tetapi kecemasan atau kekhawatiran tidak memiliki objek yang jelas. Berdasarkan uraian di atas, ditarik kesimpulan bahwa gejala-gejala kecemasan sering dialami para atlet panjat tebing khususnya pada sebelum pertandingan, atlet akan mengalami gelisah karena merasa takut tidak bisa memberikan yang terbaik dalam pertandingan, detak jantung semakin kencang ketika melihat penonton memenuhi tempat pertandingan bahkan sampai sering buang air besar maupun 
buang air kecil. Panjat tebing merupakan permainan olahraga dengan tekanan yang sangat tinggi baik dari diri atlet itu sendiri maupun dari luar diri atlet, jadi kemungkinan besar gejala-gejala kecemasan akan muncul kepada setiap atlet panjat tebing sebelum bertanding, saat bertanding maupun saat menjelang akhir pertandingan.

Self confidence adalah rasa percaya pada kemampuan sendiri bahwa mampu mencapai prestasi tertentu dan apabila prestasinya sudah tinggi maka individu tersebut akan lebih self-confidence. Selfconfidence akan menimbulkan rasa aman yang dapat dilihat dari sikap dan tingkah laku yang tampak tenang, tidak mudah ragu-ragu. Tidak mudah gugup, dan tegas. Atlet yang penuh percaya diri (fullconfidence) biasanya menetapkan target sesuai dengan kemampuannya sehingga berusaha untuk mencapai target tersebut. Apabila mengalami kegagalan, akan dihadapi dan diterima dengan lapang dada tampa harus frustasi Apta Mulsidayu(2014:102). Sedangkan menurut Ria Lumintuarso (2013:119) rasa percaya diri adalah hasil dari pertandingan tujuan dan kemampuan yang dimiliki atlet akan memiliki self confidence jika mereka mempercayai kemampuan untuk mencapai tujuan (you only achieve what you believe). Kepercayaan diri merupakan kontrol internal terhadap perasaan seseorang akan adanya akan adanya kekuatan dalam dirinya, kesadaran akan kemampuannya, dan bertanggung jawab terhadap terhadap keputusan yang telah di tetapkannya. Komarudin (2013:69).

Berdasarkan pendapat diatas, dapat disimpulkan self-confidence adalah keyakinan pada diri sendiri untuk mencapai sesuat/target yang telah di tentukan. Berikut aspek-aspek khusus tentang percaya diri dalam olahraga antara lain:
1. Keyakinan tentang kemampuan seseorang untuk melaksanakan keterampilan fisik.

2. Keyakinan tentang kemampuan seseorang untuk menggunakan keterampilan psikologis.

3. Kepercayaan untuk menggunakan keterampilan persepsi (pengambilan keputusan).

4. Kebugaran fisik dan status pelatihan percaya diri dalam satu potensi belajar atau kemampuan untuk meningkatkan keterampilan seseorang.

Menurut Hardiyono, B. 2019, Keterkaitan antara percaya diri dengan prestasi yang dapat dicapai sangat erat, hal ini juga berkaitan dengan kekuatan mental, dimana kekuatan mental ini akan turut menentukan berbagai tindakan dan keputusan yang diambil atlet panjat tebing, sehingga wujud tindakan yang dilakukan merupakan representasi dari kemampuan pikirannya dalam mengontrol kegiatan sesuai dengan keinginan. Dalam olahraga prestasi,seperti olahraga panjat tebing atlet umumnya dihadapkan pada situasi-situasi yang penuh dengan ketegangan. Situasi yang penuh dengan ketegangan itu terjadi karena atlet panjat tebing merasa takut atau tegang dalam menghadapi sesuatu yang dianggap mengancam harga dirinya situasi tersebut dirasakan menimbulkan ketegangan pada atlet panjat tebing. Situasi yang penuh dengan ketegangan tersebut merupakan tantangan bagi atlet, proses menyesuaian atau adaptasi untuk menghadapi situasi tegang perlu dilatihkan kepada atlet panjat tebing agar tidak menimbulkan ketegangan yang berlebihan yang berakibat timbulnya kecemasan, untuk mengatasi situasi ketegangan dibutuhkan kepercayaan diri. 


\section{METODE}

Penelitian ini merupakan penelitian deskriptif dengan metode survei. Menurut Saifuddin Azwar (2012: 7) penelitian deskriptif adalah penelitian yang bertujuan untuk menggambarkan secara sistematik dan akurat fakta dankarakteristik mengenai populasi atau mengenai bidang tertentu. Menurut Syofian Siregar (2010: 2) penelitian deskriptif adalah penelitian yang berkenaan dengan bagaimana cara mendeskripsikan, menggambarkan, menjabarkan, atau menguraikan data sehingga mudah dipahami.

Populasi yang digunakan pada penelitian ini adalah Atlet Panjat Tebing Pemusatan Latihan Daerah (PELATDA) Pengprov Federasi Panjat Tebing Indoesia (FPTI) Sumatera Selatan berjumlah 30 orang. Dalam pengambilan sampel ini menggunakan taknik total sampel, Instrumen atau alat yang digunakan dalam penelitian ini menggunakan angket tertutup, Data dianalisis secara deskriptif dengan persentase. Data yang telah didapat selanjutnya data akan dianalisis menggunakan persentase.

\section{HASIL DAN PEMBAHASAN}

Hasil perhitungan mencari persentase dari faktor intriksik dan faktor ekstrinsik yang mempengaruhi tingkat kecemasan dan tingkat percaya diri atlet Panjat Tebing Pemusatan Latihan Daerah (PELATDA) Pengprov Federasi Panjat Tebing Indoesia (FPTI) Sumatera Selatan, lebih jelasnya dapat dilihat berikut ini:

1. Tingkat kecemasan

a. Faktor Intrinsik

Hasil perhitungan faktor intrinsik berupa moral, pengalaman bertanding, pikiran negatif, pikiran puas diri dapat dilihat pada tabel dibawah ini:
Tabel 1. Frekuensi dan Persentase

Kecemasan Untuk Faktor intrinsik

\begin{tabular}{l|c|c}
\hline \multicolumn{3}{c}{ Faktor Instrinsik } \\
\hline \multicolumn{1}{c|}{ Indikator } & Frekuensi & $\%$ \\
\hline Moral & 13 & $4.088 \%$ \\
\hline Pengalaman Bebanding & 9 & $2.83 \%$ \\
\hline Pikiran Negatif & 8 & $2.512 \%$ \\
\hline Pikiran Puas sendiri & 17 & $5.346 \%$ \\
\hline \multicolumn{1}{c|}{ jumlah } & 47 & $14.78 \%$ \\
\hline
\end{tabular}

\section{b. Faktor Ekstrinsik}

Hasil perhitungan faktor ekstrinsik berupa pelatih dan manajer, penonton, lawan, wasit, sarana prasarana, cuaca dapat dilihat pada tabel dibawah ini:

Tabel 2. Frekuensi dan Persentase

Kecemasan Untuk Faktor Ekstrinsik

\begin{tabular}{|c|c|c|}
\hline \multicolumn{3}{|c|}{ Faktor Ekstrinsik } \\
\hline Indikator & Frekuensi & $\%$ \\
\hline Pelatih dan Manajer & 57 & $17.925 \%$ \\
\hline Penonton & 55 & $17.296 \%$ \\
\hline Lawa & 50 & $13.123 \%$ \\
\hline Wasit & 54 & $16.981 \%$ \\
\hline Sarana Prasarana & 26 & $8.176 \%$ \\
\hline Cuaca & 29 & $9.119 \%$ \\
\hline jumlah & 271 & $85.22 \%$ \\
\hline
\end{tabular}

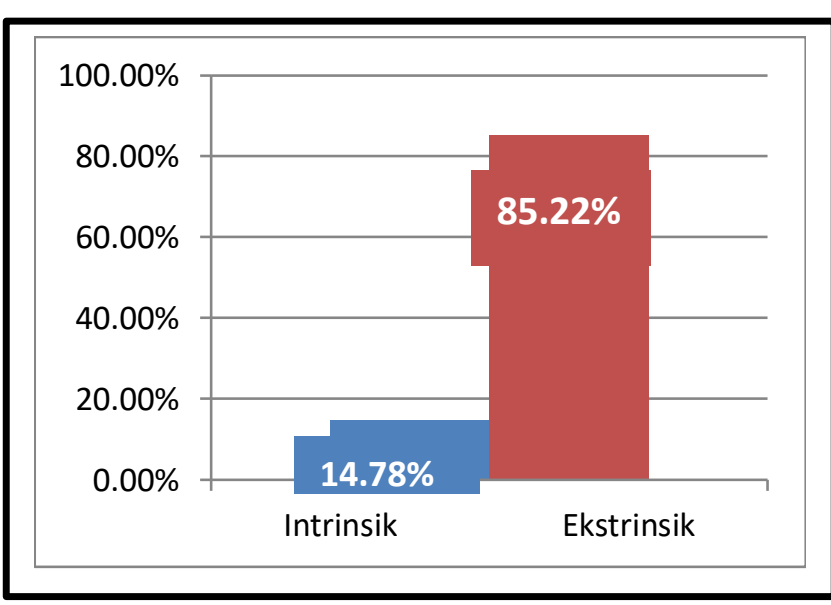

Gambar 1. Diagram Frekuensi dan

Persentase Kecemasan Untuk Faktor Ekstrinsik

Secara keseluruhan analisis dapat disimpulkan bahwa faktor intrinsik dalam kategori rendah $14.78 \%$, karena faktor intrinsik merupakan faktor yang ada pada dalam diri atlet sehingga bisa dilatihkan selama proses latihan. Sedangkan faktor 
ekstrinsik dalam kategori tinggi 85.22\%, karena faktor ekstrinsik merupakan faktor yang ada pada luar diri atlet sehingga kecemasan bisa terjadi kapan saja di luar dugaan atlet. Indikator yang mempengaruhi faktor ekstrinsik adalah pelatih dan manajer, penonton,lawan, wasit, sarana prasarana, cuaca.

Berdasarkan hasil data diatas diketahui bahwa, hasil dari faktor intrinsik dengan nilai pesentase $14.78 \%$ sedangkan faktor ekstrinsik dengan nilai persentase 85.22\%. maka dari hasil tersebut menunjukan bahwa faktor ekstinsik lebih tinggi tingkat kecemasan atlet Panjat Tebing Pemusatan Latihan Daerah (PELATDA) Pengprov Federasi Panjat Tebing Indoesia (FPTI) Sumatera Selatan

2. Tingkat Percaya Diri

a. Faktor intrinsik

Hasil perhitungan faktor intrinsik berupa mengontrol emosi, mampu menyesuaikan diri, target, optimis, harga diri, kemampuan dan usaha dapat dilihat pada tabel dibawah ini:

Tabel 3. Frekuensi dan Persentase Percaya Diri Untuk Faktor intrinsik

\begin{tabular}{l|c|c}
\hline \multicolumn{3}{c}{ Faktor Instrinsik } \\
\hline \multicolumn{1}{c}{ Indikator } & Frekuensi & $\%$ \\
\hline Mengontrol emosi & 28 & $11.522 \%$ \\
\hline $\begin{array}{l}\text { Mampu } \\
\text { menyesuaikan diri }\end{array}$ & 25 & $10.288 \%$ \\
\hline Target & 29 & $11.934 \%$ \\
\hline optimis & 28 & $11.522 \%$ \\
\hline Harga diri & 56 & $23.045 \%$ \\
\hline $\begin{array}{l}\text { Kemampuan dan } \\
\text { usaha }\end{array}$ & 29 & $11.934 \%$ \\
\hline \multicolumn{1}{c}{ jumlah } & 195 & $80.245 \%$ \\
\hline
\end{tabular}

b. Faktor ekstrinsik

Hasil perhitungan faktor intrinsik berupa mengontrol dukungan dari penonton, sarana prasaran, cuaca, pelatih dan manajer dapat dilihat pada tabel dibawah ini:
Tabel 4. Frekuensi dan Persentase Percaya Diri Untuk Faktor Ekstrinsik

\begin{tabular}{|c|c|c|}
\hline \multicolumn{3}{|c|}{ Faktor Ekstrinsik } \\
\hline Indikator & Frekuensi & $\%$ \\
\hline Dukungan dari penonton & 11 & $4.526 \%$ \\
\hline Sarana prasarana & 12 & $4.938 \%$ \\
\hline Cuaca & 13 & $5.349 \%$ \\
\hline Pelatih dan manajer & 12 & $4.938 \%$ \\
\hline Jumlah & 48 & $19.755 \%$ \\
\hline
\end{tabular}

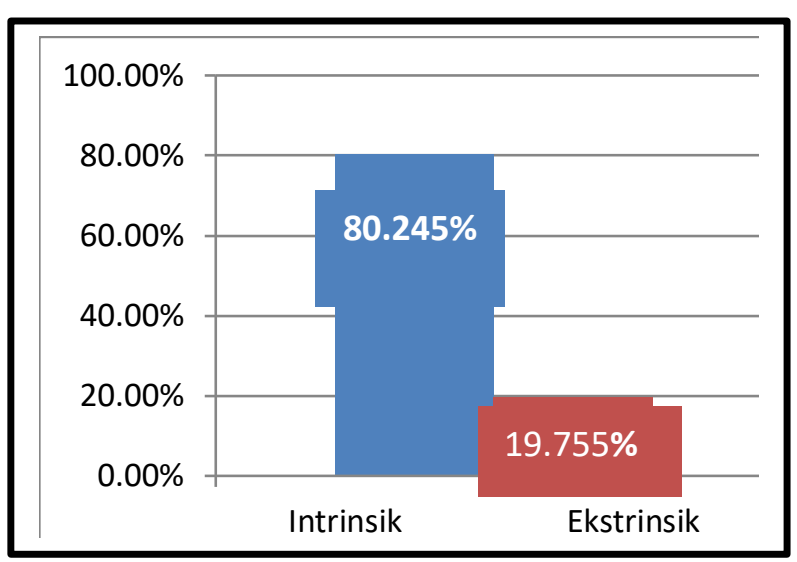

Gambar 2. Diagram Frekuensi dan Persentase Percaya Diri Untuk Faktor Ekstrinsik

Secara keseluruhan analisis dapat disimpulkan bahwa faktor intrinsik dalam kategori tinggi $80.245 \%$, karena faktor intrinsik merupakan faktor yang ada pada dalam diri atlet sehingga bisa dilatihkan selama proses latihan. Indikator yang mempengaruhi faktor intrinsik adalah Mengontrol emosi, Mampu menyesuaikan diri, Target, optimis, harga diri, kemampuan dan usaha. Sedangkan faktor ekstrinsik dalam kategori rendah 19.755\% karena faktor ekstrinsik merupakan faktor yang ada pada luar diri atlet sehingga kecemasan bisa terjadi kapan saja di luar dugaan atlet. Indikator yang mempengaruhi faktor ekstrinsik adalah, dukungan dari penonton, sarana prasarana, cuaca. pelatih dan manajer.

Berdasarkan hasil data diatas diketahui bahwa, hasil dari faktor intrinsik dengan nilai pesentase $80.245 \%$ sedangkan faktor ekstrinsik dengan nilai persentase $19.755 \%$ maka dari hasil tersebut 
menunjukan bahwa faktor intrinsik lebih tinggi tingkat percaya diri atlet Panjat Tebing Pemusatan Latihan Daerah (PELATDA) Pengprov Federasi Panjat Tebing Indoesia (FPTI) Sumatera Selatan.

\section{KESIMPULAN}

Hasil penelitian tingkat kecemasan dan tingkat percaya diri atlet atlet Panjat Tebing Pemusatan Latihan Daerah (PELATDA) Pengprov Federasi Panjat Tebing Indoesia (FPTI) Sumatera Selatan sebelum menghadapi pertandingan dan pada saat menghadapi pertandingan pada faktor intrinsik dan faktor ekstrinsik.

1. Tingkat Kecemasan

Secara keseluruhan analisis dapat disimpulkan bahwa faktor intrinsik dalam kategori rendah $14.78 \%$, karena faktor intrinsik merupakan faktor yang ada pada dalam diri atlet sehingga bisa dilatihkan selama proses latihan. Indikator yang mempengaruhi faktor intrinsik adalah moral, pengalaman bertanding, pikiran negatif, pikiran puas diri. Sedangkan faktor ekstrinsik dalam kategori tinggi $85.22 \%$, karena faktor ekstrinsik merupakan faktor yang ada pada luar diri atlet sehingga kecemasan bisa terjadi kapan saja di luar dugaan atlet. Indikator yang mempengaruhi faktor ekstrinsik adalah pelatih dan manajer, penonton,lawan, wasit, sarana prasarana, cuaca.

2. Tingkat Percaya Diri

Secara keseluruhan analisis dapat disimpulkan bahwa faktor intrinsik dalam kategori rendah $19.755 \%$ karena faktor intrinsik merupakan faktor yang ada pada dalam diri atlet sehingga bisa dilatihkan selama proses latihan. Indikator yang mempengaruhi faktor intrinsik adalah Mengontrol emosi, Mampu menyesuaikan diri, Target, optimis, harga diri,kemampuan dan usaha. Sedangkan faktor ekstrinsik dalam kategori tinggi 80.245\%, karena faktor ekstrinsik merupakan faktor yang ada pada luar diri atlet sehingga kecemasan bisa terjadi kapan saja di luar dugaan atlet. Indikator yang mempengaruhi faktor ekstrinsik adalah, dukungan dari penonton, sarana prasarana, cuaca. pelatih dan manajer.

\section{DAFTAR PUSTAKA}

Azwar, Saifuddin. (2012). Metode Penelitian. Yogyakarta: Pustaka Pelajar.

Gunarsa, D Singgih. (2008). Psikologi Olahraga Prestasi. Jakarta: Gunung Mulia.

Hustdarta. 2010. Psikologi Olahraga. Bandung: Alfabeta.

Hardiyono, B. 2019. "The effect of the dominant muscle strength and self confidence on the results climb of the rock climbing's athlete". Jurnal SPORTIF : Jurnal Penelitian Pembelajaran, Vol. 5 (1), 124-139 https://doi.org/10.29407/js_unpgri.v $5 i 1.12857$.

Hardiyono, B. 2019, "Pengaruh Latihan Tiga Gerakan Push Up Terhadap Kemampuan Kekuatan Atlet Porwil Panjat Tebing Sum-Sel" Jurnal IImu Keolahragaan Vol. 18 (2), Juli Desember 2019: 72 - 78 DOI: https://doi.org/10.24114/jik.v18i2.15 844.

Komarudin. (2013). Psikologi Olahraga. Bandung: Remaja Rosdakarya.

Komarudin dan Yusuf $\mathrm{H}$. Psikologi Olahraga. Latihan Keterampilan Mental dalam Olahraga Kompetitif Bandung: PT. Remaja Rosdakarya, 2015.

Mylsidayu, Apta. (2015). Psikologi olahraga. Jakarta: PT Bumi Aksara.

Setiadarma, Monty P. (2000:10-11), Dasar-Dasar Psikologi Olahraga. Jakarta ; Pustaka Sinar Harapan.

Siregar, Syofian. (2010). Statistika Deskriptif Untuk Penelitian. Jakarta: RajaGrafindo Persada. 
Tangkudung, James dan Apta Mylsidayu. 2017. Mental Training Aspek-Aspek Psikologi dalam Olahraga. Bekasi: Cakrawala Cendikia.

Wijaya, R., Yarmani, Y., \& Sugihartono, T. (2017). Kontribusi Kekuatan Otot Lengan dan Kekuatan Tangan Terhadap Kecepatan Memanjat Pada Olahraga Panjat Tebing di Ukm Pecinta Alam Universitas Bengkulu. Kinestetik: Jurnal IImiah Pendidikan Jasmani, 1(1), 20-27. 